\title{
Study on the Status Quo of Education Piano for Social Children
}

\author{
He Zhang \\ Shaanxi Normal University \\ Xi'an, China
}

\begin{abstract}
With the development of China's economic level and the improvement of people's overall quality, the number of children learning piano in China has risen sharply in recent years, social children piano education industry in the booming development of the same time, there are various problems. This paper explores the current situation of education for children piano in China, from three aspects of the question teachers, teaching and parents, and gives advice. We hope to contribute to education industry for children piano in our society.
\end{abstract}

Keywords-Children's piano education; social status; existing problems; suggest

\section{INTRODUCTION}

With the rapid development of China's social economy, while the living standard of residents has been greatly improved, people's demand for spiritual culture has become increasingly strong. People's overall cultural level has improved, and parents pay more attention to children's comprehensive quality education, children have a natural love for music, which has caused the number of children in China to rise sharply in recent years, and there has been a trend of "learning piano fever". In the 1990s, the central music institute conducted a survey of 3,300 piano children. In one survey, piano learning accounted for $42 \%$ of all instruments [1]. Along with the development of the social piano education, in addition to raising children's sentiment, cultivating children learning piano music accomplishment, improve children's art aesthetic, it is also the reserve of talents for piano related majors in colleges and universities. Along with the trend of "learning piano fever ", various art education institutions have emerged in the society, an overwhelming number of training schools, online courses and various accompanying apps are being promoted. In this rapid development, education piano industry of social children has presented an unprecedented complex situation. For example, the number of piano teachers is on the rise in a straight line, but the teaching level is mixed, and the teaching content is not professional, the influence of piano level examination on parents' concept of learning piano and the lax management of art training institutions, these are the problems existing in education of piano for children in today's society. These problems directly led to the present society especially in the amateur piano education industry children's piano education which on the one hand, there is a deviation from normal phenomenon, making it difficult for the industry's future development.

\section{PROBLEMS OF EDUCATION FOR CHILDREN PIANO IN CHINA}

China's social children piano education in today's social environment, despite the booming trend, we can still find some hidden problems behind the prosperity.

\section{A. The Quality of Teachers Is Mixed}

At present, the teachers of education piano for social children are mainly composed of two aspects. On the one hand, students majoring in art in music professional college or normal university work part-time as piano teachers. On the other hand, they are teachers who graduated from professional schools and are specialized in teaching piano for children.

The disadvantages of part-time teaching as a piano teacher for college students are as follows:

1) College students have heavy learning tasks and may not devote much energy to piano teaching and research in their spare time: Piano teaching is not just about teaching piano playing skills, besides teaching piano playing skills, it also needs to integrate pedagogy and psychology in the teaching process, which is a comprehensive teaching process, the piano teaching method must be studied by the piano teacher.

2) College students lack teaching experience: College students are young, have short teaching time, and have little contact with students, relatively speaking, they lack certain teaching experience. Teaching for them in this period is a process of accumulation of experience, teaching in the groping process. Then, in the teaching process may not be able to timely solve students' technical problems, thus affecting students' learning progress.

3) College students cannot guarantee the continuity of teaching: College students have limited time in school, which involves a series of problems such as finding jobs after graduation. They cannot guarantee a long-term teaching, nor can they guarantee the continuity of students' learning. Students cannot accept the systematic piano teaching will affect their learning progress. 
In addition to the college students in professional colleges, there are also some problems among the professional teachers who specialize in teaching piano for children.

a) The level of professional piano teachers is uneven: Most teachers who are engaged in professional piano teaching for children are graduated from the piano major of music university or the art major of music education of normal university, this part of the teachers have carried out systematic piano learning since childhood, there are more solid piano playing skills and professional knowledge of teaching theory. However, there are still a small number of teachers engaged in piano teaching for children. Although they graduated from music university, but at school, they chose majors similar to vocal music, theory or other instrumental music, some teachers even come from nonprofessionals who can play the piano, they may simply see the explosive trend of education for children's pianos and the considerable economic benefits it brings, therefore, they all join the ranks of children piano teachers [2].

b) The problem of teaching concept and responsibility: In the professional group of children piano teachers, a small number of teachers have some problems in the sense of responsibility and teaching philosophy. These teachers take economic interests as the first priority and blindly cater to the vanity of some parents, the teaching of students does not start from the basic skills of piano playing, music performance and other aspects, but only takes piano grade examination and participating in some social amateur competitions as the purpose of students' learning. Students seem to have high grades, but they don't have the actual piano playing skills they should have, as a result, parents and students themselves do not have a clear understanding of their true piano leve, and students can't experience the fun of music in the process of learning the piano, This has also had an extremely bad influence on the whole education piano industry.

\section{B. Problems in Piano Teaching for Social Children}

1) Teachers do not attach importance to the training of students' basic skills: Basic skills are like the foundation of a building. Only when the foundation is laid firmly can the building be built high and strong. The piano teacher cannot rush for success, students should be required to start with the basic hand shape, as well as the subsequent touch keys, the independence of fingers and so on. As students study longer, after a certain degree of difficulty has been reached in the play, the lack of solid basic skills will lead students to fail to perform the required speed and technical requirements of the music, and the musical quality of the music will also be restricted by finger technology, as a result, many students finally give up the piano study, which may even delay many talented children in music [3].

2) Teachers do not pay attention to musical notation, playing techniques are not standardized: In teaching, some teachers only pay attention to the correctness of notes and rhythms, and ignore the playing methods of musical sentences, small connections and some music marks, So that students cannot play the piano should have the sound color, music sentence and music paragraph confusion, music style error. As a result, students' music sense is directly affected and they cannot understand the emotional content of the music.

3) The teaching purpose is not to improve students' playing skills: Among the problems in the teaching team of children piano teachers, we have already mentioned, driven by the piano grading examination and the social amateur competition system, the teaching contents of some teachers are mainly textbooks or competitions of piano grading examination. Many students take piano tests every year, even twice a year. Many students and parents even believe that piano learning is over when all the piano grading exams are completed. These students only practice three pieces of music for the exam every day, the students' actual playing level is seriously out of line with the teaching content, The skill of playing is not enough to master the music of the examination, it's boring to practice the same thing over and over again for months. As a result, students could not perform well the music of the exam, and the normal piano teaching content was delayed.

4) Teachers do not pay attention to the cultivation of students' music aesthetics: The cultivation of musical sense is an important part of learning music. Piano playing cannot only play musical notes mechanically. If only blindly carries on the technical training, will make the student because of the boring practice and produces the weariness mood. Through the teacher's detailed explanation of the music, students should feel the emotion to be expressed in the music, guide the students to express the style and inner emotion of the works in piano performance, so as to improve their interest in learning and their artistic aesthetic ability in music.

\section{Parents Have a Problem with Their Children's Concept of Learning the Piano}

Parents' ideas and thinking mode determine a child's learning mode and final learning results. Parents are the supporters and helpers of children's learning [4]. The influence of parents on children's piano learning is mainly as follows:

- As the difficulty of the music deepens, some technical difficulties will appear in the process of practicing the piano, which will make them feel afraid. There are also some children who lose interest in learning because they feel dull and boring in the process of practicing. Some parents are extremely impatient when their children have these problems, they do not take the right way to help children out of the trough, but will use violence to discourage children's enthusiasm. Some parents are even indifferent to their children's learning, believing that their children's academic performance is entirely a matter of teachers, 
which eventually leads to the interruption of their children's piano learning.

- Some parents have serious vanity in their children's piano lessons and blindly pursue utilitarian ones. They do not pay attention to the cultivation of children's basic piano skills, do not care whether the children's artistic accomplishment can be improved, only blindly compete with the grade examination results, and even disrupt teachers' teaching plans. The end result is that parents spend a lot of money on tuition, children spend a lot of time, and then they don't learn anything.

- Parents cannot urge their children to practice piano on time every day after attending classes with their children. Most children have no initiative in piano learning, especially after learning for a period of time, the exercises begin to become a little difficult, they will have more fear, at this time, parents must supervise their children's piano practice. There are many reasons why parents cannot urge their children to practice the piano every day, some of which are due to the lack of understanding of learning the piano and the lack of awareness of practicing the piano. Some of it is because parents are busy and don't have enough energy. Some parents spoil their children for fear of their children's hard work. In a word, no matter what the reason, not enough practice is the direct cause of poor piano learning effect, it will eventually lead to poor quality of children's homework, which will affect their confidence and enthusiasm in learning and make them more reluctant to practice. This vicious circle will eventually prevent children from continuing to learn the piano.

\section{SUGgestions FOR EDUCATION PIANO FOR CHILDREN IN CHINESE SOCIETY}

\section{A. Optimize the Teaching Staff and Improve the Overall Professional Quality of Teachers}

As a guide in piano learning, the professional quality of piano teachers will directly influence the learning quality of students. Training in the arts of current social organizations or social art school teacher team personnel composition is more complicated, there are some professional is not solid, the lack of experience in teaching piano teacher, piano teachers need optimization.

First, art training institutions or social art schools need to promote piano teacher employment threshold, should begin from professional piano music colleges or normal universities music education professional piano selection of the graduates in the direction. We must standardize the evaluation mechanism for teachers' entry into the workplace. When hiring teachers, they should not only test their professional skills, but should start from the aspects of "playing" and "teaching ".

Secondly, as a professional child piano teacher education, we should participate in more professional lectures, master classes, training courses and other activities. Through these academic exchanges, can not only improve their professional accomplishment, doubts or difficult to appear on the solution in the teaching, also can learn many advanced education ideas and teaching methods at home and abroad. Children's piano teachers also can be controlled by a large number of network course resources, related books, academic papers, etc., some teaching methods of learning, to improve their professional level and teaching ability.

\section{B. Scientific Teaching Methods}

1) Teachers should pay attention to the training of students' basic skills and teach correct performance techniques: Basic skills are the cornerstone of high-level piano performance. Teachers should start from the initial learning stage of students and make strict requirements on students from the aspects of sitting position, relaxed state, hand shape and fingers. These aspects are interlinked and will directly affect the state of piano performance and the effect of piano performance. In addition, teachers should pay attention to the various music symbols in the music score, and teach students to play the music with correct playing techniques, instead of only requiring notes and rhythms. Music symbol is not only a training of playing skills, but also an important expression of music style and music emotion.

2) Teachers should pay attention to the cultivation of students' music aesthetics: Piano is an art of sound [5]. Every piano piece contains the composer's thoughts and feelings. In addition to explaining the music score, teachers should also explain the melody, background, composer and other aspects of the music so that students can experience the emotions the music should express. Can also be inspired or guide ways, so that the students imagination, in improving students' interest in learning and training students in the play emotional expression ability, improve the students' music aesthetic ability.

3) Teachers should have reasonable teaching plans: Learning piano is a long process, and a reasonable teaching plan is crucial to a student's learning career. Teachers should make reasonable teaching plans according to students' learning conditions, including the selection of teaching materials and the learning progress. The purpose of teaching should be to improve students' performance, not to take piano level examination as the ultimate goal of teaching. Arrange the piano grading test in the normal teaching plan, and select the piano grading according to the students' real performance level, so as not to delay the normal teaching progress.

\section{Pay Attention to Parents' Guidance, so that Parents Have a Correct Understanding of Piano Learning}

1) Pay attention to guiding children's learning: In the process of learning the piano, the child will be tired of learning for various reasons, parents should understand their children's psychological characteristics, and work with 
teachers to improve their children's interest in learning and help them out of the learning trough, we should try our best to avoid using language or behavior violence to discourage children from learning, and even more, we should not give up learning piano because children are tired of learning. It's also an exercise in children's willpower. Parents can learn together with their children, make child a parent's teacher, enjoy piano music with child, listen to concerts, read piano or composer related stories and books to increase your child's interest in learning.

2) Cultivate good piano practice habits of children: Nowadays, children are under great academic pressure, especially after entering the fourth grade of primary school, they will attend various remedial classes of cultural courses. Parents need to help their children arrange their study and practice time properly, and prevent them from wasting their practice time by using the toilet, drinking water and eating fruit, let the children know that piano work is as important as school work. At the same time, we should exercise the independence of children to practice the piano, we should give our children sufficient trust, train their ability to think independently and solve problems, parents should pay attention to ways and means to urge their children to practice the piano.

3) Have a correct understanding of piano level examination and social piano competition: Piano grading tests and piano competitions are designed to test students' learning achievements and teachers' teaching level, but due to the imperfect system, many parents have wrong ideas. Some parents ignore their children's real level and blindly test their children to a higher level. Take kids to some forprofit or promotional social piano competitions, and as long as hand in the application fee, can obtain good rank surely. These behaviors lead children to misunderstand their real piano skills, and blind confidence without the ability to resist setbacks is a stumbling block in their learning.

Parents should not to show off their children piano grade examination as well as many social piano competition results, this kind of meaningless comparison will not only hurt the child's body and mind, serious will lead to child's aversion to piano psychological.

\section{CONCLUSION}

In China there are millions of children are the benefit of the influence of the piano art, the piano is an important content of quality education, and social children piano education is also the basis of China's piano education. Although social children piano education has many problems in the current social environment, it is also a necessary stage in the development of education in China's social piano. It is believed that through the efforts of all sectors of society, China's children piano education career will be more professional, more standardized, and train more high-quality children with good personality.

\section{REFERENCES}

[1] Qin Daze.Talking about the basic quality and ability that The piano teachers should be equipped with-To Hohhot City area as an example[D]. Inner Mongolia normal university.2015-06.

[2] Zhang Xuejie.A Investigation and Study on the Current Situation of Social Children Piano Music Education of Jinan City[D]. Inner Mongolia normal university.2016-06

[3] Song Xiaodan. Research on the status and development of urban social piano education under the third line[J].Modern music.201510,pp:95-97.

[4] Wang Wei. Thoughts about Social Piano Education[J]. Piano Attistry. 2018-03,pp:40-41.

[5] Hao Jiahang. Analyze the problems and solutions of social piano education[J].Yellow river of the song.2015-13,pp21.

[6] Wang Shunan,MA Dong-ni. On the development of social piano education[J]. Yellow river of the song.2010-10,pp:120-121.

[7] Yang Yaokun. My view on social piano education[J]. $14 \mathrm{rd}$ ed.Yellow river of the song.2017,pp:51. 